\title{
PELATIHAN PENDIDIKAN KESEHATAN SEKOLAH BAGI SISWA SMA NEGERI 1 PAYUNG KEPULAUAN BANGKA SELATAN
}

\author{
M. Taheri Akhbar ${ }^{1}$, Rury Rizhardi ${ }^{2}$, Endie Riyoko ${ }^{3}$, Ilham Arvan Junaidi ${ }^{4}$, \\ Farizal Imansyah $^{5}$, Bambang Hermansah ${ }^{6}$, Bayu Iswana ${ }^{7}$, \\ Maya Kurnia $^{8}$, Asriansyah ${ }^{9}$, Widaya Handayani ${ }^{10}$ \\ Program Studi Pendidikan Olahraga Universitas PGRI Palembang \\ Email: herideta@gmail.com
}

\begin{abstract}
Abstrak
Kegiatan pelatihan pendidikan kesehatan mampu memberikan pemahaman terhadap siswa dalam melaksanakan dan menerapkan gaya hidup sehat. Siswa dapat memahami tahapan pola hidup sehat menuju tahapan bugar. Selain itu siswa mengetahui beberapa hal penting guna menjaga kesehatan dan kebugaran seperti aktifitas jasmani, bahaya merokok serta fungsi organ tubuh yang terlibat dalam menjaga kesehatan. Melalui pelatihan ini diharapkan siswa menerapkan pola hidup sehat dan beberapa hal yang menghambat menuju manusia sehat dan bugar di SMA Negeri 1 Payung Kepulauan Bangka Selatan.

Kata kunci: Pelatihan Pendidikan Kesehatan Sekolah, PMI, Siswa
\end{abstract}

\begin{abstract}
School health education training activities are able to provide an understanding of students in implementing and implementing a healthy lifestyle. Students can understand the stages of a healthy lifestyle towards the fit stage. In addition students know several important things in order to maintain health and fitness such as physical activity, the dangers of smoking and the function of organs involved in maintaining health Through this training students are expected to apply healthy lifestyles and some things that hamper toward healthy and fit humans in SMA Negeri 1 Payung Kepulauan Bangka Selatan.
\end{abstract}

Keywords: Training, School Health Education, PMI, Student 


\section{PENDAHULUAN}

Berdasarkan UU RI Nomor 20 tentang sistem pendidikan nasional dan PP RI Nomor 10 Tahun 1999 bahwa perguruan tinggi dapat menyelenggarakan pengabdian pada masyarakat sesuai dengan sifat pengetahuan dan tujuan pendidikan tinggi yang bersangkutan. Pengabdian pada masyarakat adalah kegiatan yang memanfaatkan ilmu pengetahuan dalam upaya memberikan sumbangan demi kemajuan masyarakat. Sekolah adalah wadah dalam mencapai tujuan pendidikan nasional, salah satu mata pelajaran yang mempunyai peran penting dalam mencapai tujuan tersebut adalah Penjaskesrek. Dengan mata pelajaran penjaskesrek siswa tidak hanya dituntut memiliki kesegaran jasmani yang baik namun juga akan meningkatkan pemahaman siswa dalam berperilaku hidup sehat. Sehingga mahasiswa akan memiliki kesadaran akan pentingnya menjaga agar tubuh terhindar dari penyakit. Tujuan tersebut tertuang dalam pasal 25 ayat 3 UU no. 3 tahun 2005 tentang Sistem Keolahragaan Nasional. Adapun isi dari pasal 25 ayat 3 adalah pembinaan dan pengembangan Olahraga Kesehatan pada semua jenjang pendidikan memberikan kebebasan kepada peserta didik untuk melakukan kegiatan sesuai dengan bakat dan minat.

Kesehatan menurut (Organisasi Kesehatan Dunia (WHO): 1947) menyatakan kesehatan adalah suatu keadaan fisik, mental, dan sosial kesejahteraan dan bukan hanya tidak adanya penyakit atau kelemahan. Menurut Kementerian Kesehatan Republik Indonesia (Menkes RI) yang mendefinisikan kesehatan yaitu merupakan keadaan normal dan sejahtera anggota tubuh. Menurut (Majelis Ulama Indonesia (MUI): 1983) kesehatan adalah merupakan ketahanan jasmani, rohani dan sosial yang dimiliki oleh manusia.

Dari berbagai sumber tersebut jelas bahwa kesehatan sangat diperlukan oleh manusia. Oleh karena itu pelatihanpelatihan perlu dilaksanakan baik di lingkungan masyrakat umum ataupun disekolah-sekolah.

\section{BAHAN DAN METODE}

Tema Kegiatan Pelatihan yaitu pelatihan pendidikan kesehatan sekolah. Lokasi pelaksanaan pelatihan kesehatan sekolah ini di SMA Negeri 1 Payung Bangka Selatan. Waktu Pelaksanaan pada tanggal 23 April 2019. Narasumber pada pelatihan ini adalah Dosen Pendidikan Olahraga dan Mahasiswa. Subyek pelatihan adalah Guru, staf dan siswa/siswi SMA Negeri 1 Payung Bangka Selatan sebanyak 58 orang.

\section{HASIL DAN PEMBAHASAN}

Berdasarkan kegiatan pelatihan yang telah dilaksanakan langkah yang dilakukan adalah dengan memberikan pelatihan kepada peserta, hasil dari pelatihan tersebut dimana para peserta dapat memahami apa itu kesehatan sekolah, bagaimana menghindari narkoba, dampak apa yang diakibatkan karena merokok, dapat mengenali sistem cardiorespirasi, dan bagaimana peserta mengupayakan secara prepentif maupun kuratif dalam pencegahan berbagai 
penyakit.

Disekolah merupakan tempat yang nyaman bagi penyakit yang akan menjangkiti para siswa. Kesehatan di sekolah sangat kompleks, hal tersebut dapat dihindari apabila para siswa maupun dewan guru dapat melakukan pencegahan, dengan selalu mengaktifkan Unit Kesehatan Sekolah (UKS). UKS harus berjalan dengan baik. Secara psikis pemateri melihat bahwa di sekolah SMA Negeri 1 Payung.

Kesehatan disekolahnya masih belum berjalan maksimal. Hal tersebut dapat dilihat dari masih adanya sampah-sampah yang berserakan, dan setelah melalui pendekatan-pendekatan terhadap para siswa, bahwa masih ada para siswa yang menjadi perokok aktif. Maka dari itulah pemateri memberikan tipstips agar segala penyakit yang akan timbul dapat dicegah. Materi yang diberikan bukan hanya pemahaman akan tetapi dilakukan juga dengan praktek langsung oleh mahasiswa.

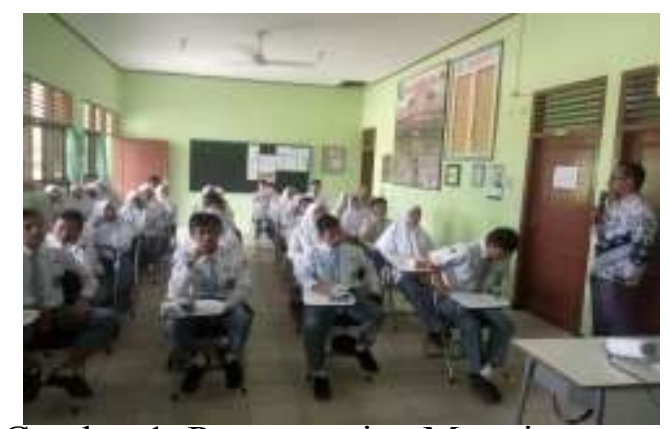

Gambar 1. Penyampaian Materi

\section{KESIMPULAN}

Berdasarkan kegiatan pelatihan yang telah dilakasanakan, maka ada beberapa hal yang dapat dismpulkan adalah sebagai berikut:

a. para dewan guru selalu dapat mensosialisasikan pentingnya kesehatan bagi siswa

b. Para siswa dapat menyadari bahwa pentingnya kesehatan bagi diri sendiri.

c. Dapat menghindari narkoba, merokok dan penyebab timbulnya berbagai penyakit.

DAFTAR PUSTAKA

Majelis Ulama Indonesia (MUI). 1983.

Menteri Kesehata Republik Indonesia

(Menkes RI)

Undang-Undang RI Nomor 20. Tentang

Sistem Pendidikan Nasional.

World Helath Organization (WHO). 1947. 